\title{
BEBAN KERJA MENTAL DAN KELUHAN KELELAHAN KERJA PADA BIDAN DI PUSKESMAS JETIS YOGYAKARTA
}

\author{
MENTALLY WORK ASSESSMENT AND EXHAUSTION WORK COMPLAINT IN \\ MIDWIFE AT PUSKESMAS JETIS YOGYAKARTA
}

\author{
Nafi'ah Nurfi Afriansyah \\ Persatuan Sarjana Kesehatan Masyarakat Indonesia (PERSAKMI) \\ E-mail: nafiah.nurfi@gmail.com
}

\begin{abstract}
The main task of midwife to support the decreasing of Maternal Mortality Rate (MMR) and Infant Mortality Rate (IMR) by midwifery services. The task of midwife was not only gave service but also as a manager, researcher, and educator in society. They need a good physical, mental health, and have a optimum performances. This aim of this research was studied mental work loads and fatigue of midwife in Puskesmas Jetis Yogyakarta. This research was observational and cross sectional approach. The sample used total population method were 15 midwifes who worked in Puskesmas Jetis Yogyakarta. Instruments for collect data used by interview, observation, and NASA-TLX with IFRC questionnaires. The results showed that physic workload category were to 46\% (Physical Demand $=14 \%$, Temporal Demand $=22 \%$, Own Performance $=10 \%)$, and mental workload category were to $54 \%$ (Mental Demand $=18 \%$, Frustation $=15 \%$, Effort $=$ $21 \%$ ), and the average of midwife fatigue on the moderate level as 9 respondents(60\%). The conclusion of this research are that mental workload of midwife heavier than their physical workload.
\end{abstract}

Keywords: psychology work load, midwife, fatigue

\begin{abstract}
ABSTRAK
Tugas utama profesi bidan adalah mendukung penurunan Angka Kematian Ibu (AKI) dan Angka Kematian Bayi (AKB) melalui pelayanan kebidanan yang berkualitas. Tugas bidan tidak hanya sebagai pelaksana pelayanan kebidanan, namun juga mempunyai peran sebagai pengelola, peneliti, dan pendidik di masyarakat. Profesi sebagai bidan merupakan pekerja yang membutuhkan kesehatan fisik dan mental yang baik, serta dituntut memiliki performa yang optimal. Pada penelitian ini bertujuan untuk mempelajari beban kerja mental dan kelelahan kerja pada bidan di Puskesmas Jetis Yogyakarta. Jenis penelitian secara observasional dan berdasarkan pendekatan waktu adalah cross sectional. Sampel dalam penelitian ini menggunakan total populasi sebanyak 15 Bidan yang bekerja di Puskesmas Jetis Yogyakarta. Instrumen yang digunakan untuk pengambilan data menggunakan kuesioner beban kerja NASA -TLX, kuesioner IFRC, wawancara, dan observasi. Hasil penelitian ini menunjukkan bahwa dimensi NASA-TLX kategori Beban Kerja Fisik sebesar 46\% (Tuntutan Fisik $=14 \%$, Tuntutan Waktu $=22 \%$, Performansi $=10 \%)$, dan kategori Beban Kerja Mental sebesar 54\% $($ Tuntutan Mental $=$ $18 \%$, Tingkat Frustasi $=15 \%$, Tingkat Usaha $=21 \%$ ), serta rata-rata tingkat kelelahan kerja sedang sebesar 9 responden $(60 \%)$. Kesimpulan dalam penelitian ini menunjukkan bahwa beban kerja mental pada bidan dirasakan lebih besar daripada beban kerja fisik.
\end{abstract}

Kata kunci: beban kerja psikologis, bidan, kelelahan kerja

\section{PENDAHULUAN}

Profesi bidan merupakan salah satu tenaga pelayanan kesehatan yang secara nasional sudah mendapatkan pengakuan dalam Undang-Undang maupun peraturan Pemerintah Indonesia dan secara internasional telah diakui oleh International Confederation of Midwives (ICM), The International Federation of Gynecology and Obstetrics (FIGO), dan World Health Organization (WHO). Seorang bidan dapat melakukan pertolongan ke masyarakat secara mandiri. Tugas, tanggung jawab, dan kewenangan profesi bidan yaitu menurunkan Angka Kematian Ibu (AKI) dan Angka Kematian Bayi (AKB) melalui pelayanan kesehatan ibu dan anak (KIA), pelayanan ibu hamil, melahirkan, nifas, pelayanan Keluarga Berencana (KB), pelayanan kesehatan masyarakat, dan pelayanan reproduksi lainnya (Hidayat \& Mufdlilah, 2008).

Peluang untuk dapat menurunkan AKI dan AKB semakin besar dengan penanganan yang tepat pada 
saat pertolongan awal kebidanan, karena pelayanan kebidanan sendiri merupakan bagian integral dari pelayanan kesehatan. Bidan sebagai pelaksana utama pelayanan kebidanan merupakan ujung tombak dalam menurunkan AKI dan AKB di Indonesia. Hal ini didukung dengan jumlah bidan di Indonesia yang cukup besar yaitu $40 \%$ dari seluruh bidan dan perawat di Indonesia (KEPMENKES RI, 2005).

Profesi bidan merupakan pekerjaan yang membutuhkan tenaga pikiran maupun tenaga fisik. Tenaga pikiran dalam hal ini seperti bidan harus mampu bekerja sesuai dengan keterampilan dan kompetensinya, bertanggung jawab terhadap pekerjaannya, harus dapat menjalin hubungan baik dalam menghadapi pasien maupun keluarga pasien, pengambilan keputusan segera pada tindakan kegawatdaruratan, menginterpretasi hasil pemeriksaan, memikirkan tindakan untuk langkah selanjutnya, dan sebagainya. Tenaga fisik berupa tindakan medis seperti pemeriksaan kehamilan, pelayanan persalinan, perawatan ibu nifas, dan penanganan kegawatdaruratan obstetri dan neonatal yang harus dilaksanakan dengan sigap, dan sebagainya. Pekerjaan sebagai bidan juga dihadapkan dengan risiko terkena infeksi karena tenaga kesehatan akan selalu berhubungan dengan darah dan cairan tubuh yang merupakan media penularan penyakit dari pasien ke tenaga kesehatan. HIV/AIDS, Hepatitis B dan Hepatitis C merupakan ancaman terbesar bagi tenaga kesehatan.

Profesi bidan dituntut selalu tanggap setiap saat menangani pasien dengan kondisi darurat seperti ibu bersalin. Selain memberikan pelayanan kesehatan ibu dan anak, tugas tambahan bidan adalah pencatatan dan pelaporan kegiatan harian dan bulanan. Menurut hasil penelitian Handayani dkk (2010) menyatakan bahwa $56,6 \%$ tenaga kesehatan menganggap dengan adanya tugas tambahan kadang mengganggu tupoksi dalam pelaksanaan pelayanan kesehatan di Puskesmas. Oleh sebab itu, beban kerja bidan secara fisik maupun mental dapat menimbulkan kelelahan kerja.

Seorang bidan dapat memberikan pelayanan kebidanan berkualitas jika memiliki performa yang baik, namun pada kenyataannya bidan sering mengalami kelelahan kerja secara fisik dan mental. Fenomena kelelahan yang sering dialami oleh bidan tidak dapat diabaikan begitu saja karena berkaitan dengan keselamatan pasien yang sedang ditangani dan dapat pula meningkatkan peluang terjadinya kecelakaan kerja. Data dari International Labour Organization (ILO) pada tahun 2010 menyebutkan bahwa setiap tahun sebanyak dua juta pekerja meninggal dunia karena kecelakaan kerja yang diakibatkan faktor kelelahan (Wicaksono, 2014).

Kelelahan kerja merupakan respons tubuh tiap individu terhadap stress psikososial yang dialami dalam satu waktu tertentu. Kelelahan kerja tidak hanya berupa kelelahan fisik dan psikis, namun berkaitan dengan penurunan kinerja fisik perasaan lelah, penurunan motivasi, dan penurunan produktivitas kerja (Maurits, 2010). Kelelahan kerja dapat menurunkan kinerja dan meningkatkan kesalahan saat bekerja sehingga menambah peluang terjadinya kecelakaan kerja. Pendapat lain mengatakan bahwa kelelahan dapat menurunkan kapasitas kerja dan ketahanan kerja yang ditandai oleh sensasi lelah, motivasi menurun, dan aktivitas menurun (Mauludi, 2010).

Pada penelitian ini berlokasi di Puskesmas Jetis. Puskesmas Jetis merupakan salah satu puskesmas yang memberikan pelayanan rawat jalan dan rawat inap bersalin di Kota Yogyakarta. Berdasarkan Keputusan Walikota Yogyakarta (2013), Puskesmas Jetis ditunjuk sebagai salah satu Puskesmas Pelayanan Obstetri Neonatal Emergensi Dasar (PONED) di wilayah Kota Yogyakarta. Puskesmas PONED memiliki pelayanan rawat inap dan mempunyai fasilitas PONED siap 24 jam untuk memberikan pelayanan terhadap ibu hamil, bersalin, nifas, dan bayi baru lahir dengan komplikasi. Puskesmas Jetis juga merupakan salah satu puskesmas peraih ISO 9001:2008 di Kota Yogyakarta (Humas Pemkot YK, 2014). Puskesmas Jetis sudah menerapkan sistem mutu pelayanan sesuai standar. Berdasarkan hasil wawancara awal diperoleh informasi bahwa jumlah pasien KIA tiap harinya berjumlah $\pm 60-80$ orang, dan jumlah persalinan tiap bulan $\pm 20-30$ pasien. Hasil wawancara awal juga menyatakan bahwa selain tugas pelayanan kebidanan, bidan juga terbebani dengan tugas administrasi yang harus dilengkapi tiap bulan seperti PWS KIA, KB Kartini, Kohort Ibu dan bayi, SIM Mundhu, Pcare, SIMPUS, Registrasi harian, Kantong Persalinan, Kantong Kewaspadaan dan lainnya.

Berdasarkan data tersebut tujuan dalam penelitian ini adalah mempelajari beban kerja mental dan keluhan kelelahan kerja pada bidan di Puskesmas Jetis. 


\section{METODE}

Penelitian ini merupakan penelitian observasional yang bertujuan untuk mempelajari beban kerja mental dan kelelahan kerja pada bidan. Apabila ditinjau dari waktu pelaksanaan, penelitian ini merupakan penelitian cross sectional. Populasi dalam penelitian ini adalah bidan yang bekerja di Puskesmas Jetis Yogyakarta yang berjumlah 15 orang. Sampel yang digunakan dalam penelitian berjumlah 15 orang yang didapatkan dengan menggunakan teknik total populasi. Lokasi penelitian di Poli KIA dan Rawat bersalin di Puskesmas Jetis Yogyakarta. Waktu penelitian dimulai dari bulan April 2016. Variabel independen dalam penelitian ini adalah beban kerja, sedangkan variabel dependen dalam penelitian ini adalah kelelahan kerja.

Teknik pengumpulan data menggunakan data primer. Data primer diperoleh dari pengisian kuesioner yang meliputi NASA-TLX, dan IFRC serta dilakukan observasi dan wawancara dengan responden. Pengumpulan data dengan pengisian kuesioner dipandu langsung oleh peneliti.

Pengolahan data dilakukan dengan editing, scoring, coding, dan entry. Analisis data dilakukan dengan distribusi frekuensi dari semua variabel untuk mengetahui frekuensinya dan tabulasi silang.

\section{HASIL}

\section{Karakteristik Responden}

Hasil penelitian berdasarkan karakteristik responden dalam penelitian ini terdiri dari karakteristik individu dan karakteristik pekerjaan. Adapun hasilnya adalah sebagai berikut pada Tabel 1 .

\section{Karakteristik Individu}

Berdasarkan Tabel 1 menunjukkan bahwa sebagian besar yaitu $53,3 \%$ bidan berumur $<40$ tahun, $80,0 \%$ bidan berpendidikan terakhir D3, $60,0 \%$ bidan memiliki masa kerja di Puskesmas Jetis selama $<5$ tahun, dan $53,3 \%$ bidan memiliki masa kerja sebagai bidan $<17$ tahun. Sebagian besar yaitu $73,3 \%$ bidan memiliki IMT normal $(73,3 \%)$, dan $60 \%$ bidan tidak memiliki riwayat penyakit, serta $73,3 \%$ bidan tidak rutin berolahraga.

\section{Karakteristik Pekerjaan}

Adapun hasil karakteristik pekerjaan dalam penelitian ini adalah sebagai berikut:

\section{Waktu Pelayanan Kebidanan}

Terlihat bahwa sebagian besar membutuhkan waktu $>4$ jam untuk menyelesaikan tugas pelayanan kebidanan yaitu sebanyak 12 responden $(20,0 \%)$, dan sebagian kecil responden membutuhkan waktu $<4$ jam sebanyak 4 responden $(26,7 \%)$.

\section{Waktu Melaksanakan Tugas Administrasi}

Terlihat bahwa sebagian besar responden membutuhkan waktu $<2$ jam untuk menyelesaikan tugas administrasi pelayanan kebidanan, yaitu sebanyak 8 responden $(53,3 \%)$, dan sebagian responden membutuhkan waktu $>2$ jam sebanyak 7 responden $(46,7 \%)$.

Tabel 1. Distribusi Frekuensi Karakteristik Responden di Puskesmas Jetis Yogyakarta

\begin{tabular}{lcc}
\hline \multicolumn{1}{l}{ Karakteristik Responden } & n & \% \\
\hline Umur & & \\
$\quad<40$ Tahun & 8 & 53,3 \\
$\quad \geq 40$ Tahun & 7 & 46,7 \\
Masa Kerja di Puskesmas & & \\
Jetis & & \\
$\quad<5$ Tahun & 9 & 60,0 \\
$\quad \geq 5$ Tahun & 6 & 40,0 \\
Masa Kerja sebagai Bidan & & \\
$\quad<17$ Tahun & 8 & 53,3 \\
$\quad \geq 17$ Tahun & 7 & 46,7 \\
IMT (Indeks Massa Tubuh) & & \\
$\quad$ Kurus & 1 & 6,7 \\
$\quad$ Normal & 11 & 73,3 \\
$\quad$ Gemuk & 3 & 20,0 \\
Pendidikan Terakhir & & \\
D3 Kebidanan & 12 & 80,0 \\
$\quad$ D4 Kebidanan & 3 & 20,0 \\
Status Kawin & & \\
$\quad$ Kawin & 13 & 67,0 \\
Belum Kawin & 2 & 13,3 \\
Rutinitas Olahraga & & \\
$\quad$ Tidak Pernah & 11 & 73,3 \\
1x seminggu & 2 & 13,3 \\
2-3 x seminggu & 2 & 13,3 \\
\hline
\end{tabular}




\section{Perbandingan Beban Kerja antara Pelayanan Kebidanan dengan Tugas Administrasi}

Terlihat bahwa sebagian besar responden memilih tugas administrasi lebih berat yaitu sebanyak 9 responden $(60,0 \%)$, sama berat sebanyak 4 responden $(26,7 \%)$, dan sisanya memilih tugas pelayanan kebidanan lebih berat yaitu 2 responden $(13,3 \%)$.

Tabel 2. Hasil Pengukuran Tiap Dimensi NASATLX

\begin{tabular}{lcc}
\hline \multicolumn{1}{c}{ Dimensi } & Total & Rata-Rata \\
\hline Tuntutan Mental (MD) & 3130 & 208,7 \\
Tuntutan Fisik (PD) & 2020 & 134,7 \\
Tuntutan Waktu (TD) & 3970 & 264,7 \\
Performansi (OP) & 1750 & 116,7 \\
Tingkat Usaha (EF) & 3930 & 262,0 \\
Frustasi (FR) & 2440 & 162,7 \\
\hline
\end{tabular}

Tabel 3. Nilai Rata-Rata dari Pembobotan Dimensi Nasa-TLX

\begin{tabular}{lcccccc}
\hline & \multicolumn{3}{c}{ Kategori Mental } & \multicolumn{3}{c}{$\begin{array}{c}\text { Kategori } \\
\text { Fisik }\end{array}$} \\
\hline & MD & FR & EF & PD & TD & OP \\
\hline Total & 41 & 34 & 47 & 31 & 50 & 22 \\
\hline Rata-Rata & 2,7 & 2,3 & 3,1 & 2,1 & 3,3 & 1,5 \\
\hline & & 8,13 & & & 6,87 & \\
\hline & \multicolumn{3}{c}{$54,0 \%$} & & $46,0 \%$ & \\
\hline
\end{tabular}

\section{Pelatihan Asuhan Persalinan Normal (APN)}

Terlihat bahwa sebagian besar responden sudah mengikuti pelatihan APN yaitu 12 responden $(80,0 \%)$, dan sisanya belum mengikuti pelatihan APN sebanyak 3 responden (20,0\%).

\section{Riwayat Penyakit}

Terlihat bahwa sebagian besar responden tidak memiliki riwayat penyakit yaitu sebanyak 9 responden $(60,0 \%)$, dan sisanya memiliki riwayat penyakit sebanyak 6 responden $(40,0 \%)$.

\section{BEBAN KERJA MENTAL}

Data beban kerja dari hasil pengukuran dengan NASA-TLX berikut ini:

Pada Tabel 2 menunjukkan bahwa skor tertinggi responden terdapat pada dimensi tuntutan waktu, tingkat usaha, dan tuntutan mental.

Berdasarkan Tabel 3 dapat disimpulkan bahwa pekerjaan pada bidan di Puskesmas Jetis Yogyakarta lebih didominasi dengan pekerjaan mental sebesar $54,0 \%$.

\section{Identifikasi Penilaian Subyektif Beban Kerja Kategori Fisik Bidan Puskesmas Jetis Yogyakarta}

Berdasarkan hasil observasi untuk penilaian beban kerja fisik bidan adalah sebagai berikut: Berdasarkan Tabel 4 menunjukkan bahwa beban kerja fisik pelayanan kebidanan yang mendominasi di Poli KIA adalah pelayanan kehamilan sebesar

Tabel 4. Identifikasi Penilaian Subyektif Beban Kerja Fisik Bidan Puskesmas Jetis Yogyakarta

\begin{tabular}{|c|c|c|c|}
\hline No & Kegiatan & \multicolumn{2}{|c|}{ Persentase } \\
\hline \multicolumn{4}{|c|}{ Bidan di Poli KIA } \\
\hline 1. & Pelayanan Kebidanan: Kehamilan & \multirow{11}{*}{$\begin{array}{c}\text { Persentase Penilaian } \\
\text { Subyektif x Rata-Rata } \\
\text { Pembobotan Dimensi NASA- } \\
\text { TLX kategori fisik }\end{array}$} & $35 \% \times 46=16,1 \%$ \\
\hline 2. & Pelayanan Kebidanan: KB & & $20 \% \times 46=9,2 \%$ \\
\hline 3. & Pelayanan Kebidanan: Bayi Balita & & $15 \% \times 46=6,9 \%$ \\
\hline 4. & Pelayanan Kebidanan: Nifas & & $10 \% \times 46=4,6 \%$ \\
\hline 5. & Pelayanan Kebidanan: Kesehatan Reproduksi & & $5 \% \times 46=2,3 \%$ \\
\hline 6. & Pencatatan dan pelaporan kegiatan/tindakan & & $15 \% \times 46=6,9 \%$ \\
\hline \multicolumn{2}{|r|}{ Bidan di Rawat Inap Bersalin } & & \\
\hline 1. & Pelayanan Kebidanan: Persalinan & & $40 \% \times 46=18,4 \%$ \\
\hline 2. & Pelayanan Kebidanan: Bayi Balita & & $30 \% \times 46=13,8 \%$ \\
\hline 3. & Pelayanan Kebidanan: Nifas & & $20 \% \times 46=9,2 \%$ \\
\hline 4. & Pencatatan dan pelaporan kegiatan/tindakan & & $10 \% \times 46=4,6 \%$ \\
\hline
\end{tabular}


Tabel 5. Identifikasi Penilaian Subyektif Beban Kerja Mental Bidan Puskesmas Jetis Yogyakarta

\begin{tabular}{|c|c|c|c|}
\hline No & Kegiatan & Perse & ntase \\
\hline & \multicolumn{2}{|l|}{ Bidan di Poli KIA } & \\
\hline 1. & $\begin{array}{l}\text { Memahami dan memperhatikan kebutuhan pasien } \\
\text { pada pelayanan kebidanan di Poli KIA }\end{array}$ & & $30 \% \times 54=16,2 \%$ \\
\hline 2. & $\begin{array}{l}\text { Menciptakan suatu rasa percaya diri sehingga pasien } \\
\text { lebih terbuka dan nyaman dengan bidan }\end{array}$ & & $15 \% \times 54=8,1 \%$ \\
\hline 3. & $\begin{array}{l}\text { Memberikan pemahaman pada pasien dan keluarga } \\
\text { terkait kondisi kesehatan pasien melalui konseling }\end{array}$ & & $10 \% \times 54=5,4 \%$ \\
\hline 4. & $\begin{array}{l}\text { Mengkaji, mendiagnosa pasien, dan merencanakan } \\
\text { tindakan selanjutnya sesuai prosedur }\end{array}$ & & $25 \% \times 54=13,5 \%$ \\
\hline 5. & Tanggungjawab pencatatan dan pelaporan & & $10 \% \times 54=5,4 \%$ \\
\hline \multirow[t]{2}{*}{6.} & $\begin{array}{l}\text { Mengevaluasi kegiatan-kegiatan yang berhubungan } \\
\text { dengan kesehatan ibu dan anak di Poli KIA }\end{array}$ & & $10 \% \times 54=5,4 \%$ \\
\hline & Bidan di Rawat Inap Bersalin & & \\
\hline 1. & $\begin{array}{l}\text { Memahami dan memperhatikan kebutuhan pasien } \\
\text { pada pelayanan kebidanan di rawat inap bersalin }\end{array}$ & & $10 \% \times 54=5,4 \%$ \\
\hline 2. & $\begin{array}{l}\text { Menciptakan suatu rasa percaya diri sehingga pasien } \\
\text { lebih terbuka dan merasa nyaman dengan bidan }\end{array}$ & & \\
\hline 3. & $\begin{array}{l}\text { Memberikan pemahaman pada pasien dan keluarga } \\
\text { terkait kondisi kesehatan pasien melalui konseling }\end{array}$ & & $20 \% \times 54=10,8 \%$ \\
\hline 4. & $\begin{array}{l}\text { Mengkaji, mendiagnosa pasien, dan merencanakan } \\
\text { tindakan selanjutnya sesuai prosedur }\end{array}$ & & $30 \% \times 54=16,2 \%$ \\
\hline 5. & $\begin{array}{l}\text { Kesiapan diri dalam menangani pasien dengan } \\
\text { kegawatdaruratan. }\end{array}$ & & $25 \% \times 54=13,5 \%$ \\
\hline 6. & Tanggung jawab terhadap pencatatan dan pelaporan & & $5 \% \times 54=2,7 \%$ \\
\hline
\end{tabular}

$16,1 \%$,dan unit rawat inap bersalin pelayanan kebidanan yang mendominasi adalah pelayanan persalinan sebesar $18,4 \%$.

Berdasarkan Tabel 5 menunjukkan bahwa beban kerja mental bidan terbesar di Poli KIA adalah pada saat memahami dan memperhatikan kebutuhan banyak pasien dalam satu waktu pelayanan. Pada unit rawat inap bersalin beban kerja mental yang terbesar adalah saat mengkaji dan mendiagnosa pasien terutama pada pasien bersalin dengan kondisi kesehatan yang dapat berubah sewaktu-waktu.

\section{Kelelahan Kerja}

Data hasil pengukuran kelelahan kerja dengan kuesioner Industrial Fatigue Research Committee (IFRC) menunjukkan bahwa sebagian besar responden dikategorikan mempunyai kelelahan kerja tingkat sedang, yaitu 9 responden $(60,0 \%)$, dan kelelahan kerja tingkat rendah terdiri dari 6 responden $(40,0 \%)$.

\section{Identifikasi Karakteristik Responden Berdasarkan Umur dan Masa Kerja dengan Kelelahan Kerja Bidan di Puskesmas Jetis Yogyakarta}

Hasil distribusi frekuensi umur dan masa kerja dengan kelelahan kerja bidan di Puskesmas Jetis Yogyakarta dapat dilihat pada tabel 6 .

Pada Tabel 6 menunjukkan bahwa mayoritas responden yang berusia $<40$ dan memiliki masa kerja di Puskesmas Jetis selama $<5$ tahun memiliki tingkah kelelahan kerja sedang sebanyak 6 responden $(75,0 \%)$ dan 5 responden $(55,6 \%)$. Pada responden yang memiliki masa kerja sebagai bidan $<17$ tahun sebagian besar memiliki kelelahan kerja tingkat sedang. 
Tabel 6. Distribusi Frekuensi Umur dan Masa Kerja dengan Kelelahan Kerja Bidan di Puskesmas Jetis Yogyakarta.

\begin{tabular}{lccc}
\hline & \multicolumn{3}{c}{ Kelelahan Kerja } \\
\cline { 2 - 4 } & Rendah & Sedang & Total \\
\cline { 2 - 4 } & $\mathbf{n} \%$ & n \% & n \% \\
\hline Umur & & \\
$<40$ Tahun & $2(25,0)$ & $6(75,0)$ & $8(100)$ \\
$\geq 40$ Tahun & $4(57,1)$ & $3(42,9)$ & $7(100,0)$ \\
\hline Masa Kerja di Puskesmas Jetis & \\
$<$ 5 Tahun & $4(44,4)$ & $5(55,6)$ & $9(100,0)$ \\
$\geq 5$ Tahun & $2(33,3)$ & $4(66,7)$ & $6(100,0)$ \\
\hline Masa Kerja sebagai Bidan & \\
$<$ 17 Tahun & $2(25,0)$ & $6(75,0)$ & $8(100,0)$ \\
$\geq 17$ Tahun & $4(57,1)$ & $3(42,9)$ & $7(100,0)$ \\
\hline
\end{tabular}

\section{PEMBAHASAN}

\section{Beban Kerja Mental Bidan di Puskesmas Jetis Yogyakarta}

Bidan adalah seorang perempuan yang lulus dari pendidikan bidan yang diakui pemerintah dan organisasi profesi di wilayah Negara Republik Indonesia serta memiliki kompetensi dan kualifikasi untuk diregister, sertifikasi, dan atau secara sah mendapatkan lisensi untuk menjalankan praktik kebidanan. Pelayanan kebidanan merupakan pelayanan professional dan merupakan bagian integral dari pelayanan kesehatan. Ruang lingkup pelayanan kebidanan berfokus pada upaya pencegahan, promosi kesehatan, pertolongan persalinan normal, deteksi komplikasi pada ibu dan anak, melaksanakan tindakan asuhan sesuai dengan kewenangan atau bantuan lain jika diperlukan, serta melaksanakan tindakan kegawatdaruratan (KEPMENKES RI, 2007).

Tugas pokok bidan adalah melaksanakan pelayanan kebidanan ibu dan reproduksi perempuan, pelayanan keluarga berencana, pelayanan kesehatan bayi dan anak serta pelayanan kesehatan masyarakat (PERMENKES RI, 2009). Bidan juga mempunyai empat peran yaitu sebagai pelaksana, pengelola, peneliti, dan pendidik (Hidayat \& Mufdlilah, 2008). Bidan menjalankan peran dan tugasnya mengacu pada standar profesi bidan. Menurut KEPMENKES RI (2007), standar profesi bidan, bidan memiliki 9 kompetensi yaitu: Bidan mempunyai persyaratan pengetahuan dan keterampilan dari ilmu-ilmu sosial, kesehatan masyarakat, dan etik yang membentuk dasar dari asuhan yang bermutu tinggi sesuai dengan budaya, untuk wanita, bayi baru lahir dan keluarganya. Bidan memberikan asuhan yang bermutu tinggi, pendidikan kesehatan yang tanggap terhadap budaya, dan pelayanan menyeluruh di masyarakat dalam rangka meningkatkan kehidupan keluarga yang sehat, perencanaan kehamilan, dan kesiapan menjadi orang tua. Bidan memberikan asuhan antenatal yang bermutu tinggi untuk mengoptimalkan kesehatan selama kehamilan yang meliputi: deteksi dini, pengobatan, atau rujukan untuk komplikasi tertentu. Bidan memberikan asuhan yang bermutu tinggi, tanggap terhadap kebudayaan setempat selama persalinan, memimpin suatu persalinan yang bersih dan aman, menangani situasi kegawatdaruratan tertentu untuk mengoptimalkan kesehatan wanita dan bayinya yang baru lahir. Bidan memberikan asuhan pada ibu nifas dan menyusui yang bermutu tinggi dan tanggap terhadap budaya setempat. Bidan memberikan asuhan yang bermutu tinggi, komprehensif pada bayi baru lahir sehat sampai dengan 1 bulan. Bidan memberikan asuhan yang bermutu tinggi, komprehensif pada bayi dan balita sehat (1 bulan-5 tahun). Bidan merupakan asuhan yang bermutu tinggi dan komprehensif pada Melaksanakan asuhan kebidanan pada wanita/ibu dengan gangguan sistem reproduksi. Keluarga, kelompok dan masyarakat sesuai dengan budaya setempat.

Berdasarkan pengukuran beban kerja mental dalam penelitian ini menggunakan kuesioner NASATLX yang terdiri dari 6 dimensi yaitu tuntutan mental (mental demand), tuntutan fisik (physical demand), tuntutan waktu (temporal demand), performansi (own performance), tingkat usaha (effort), dan tingkat frustasi (frustration) yang akan membentuk rata-rata WWL (beban kerja subyektif) dari seseorang. Secara keseluruhan dapat diketahui bahwa dimensi tuntutan waktu, tingkat usaha, dan tuntutan mental merupakan dimensi yang paling tinggi terhadap rata-rata WWL. Menurut hasil penelitian Wahyuni (2015) bahwa dimensi yang paling sering berkontribusi dalam besaran indeks WWL adalah tingkat usaha, tuntutan mental, dan tuntutan fisik.

Berdasarkan hasil penelitian ini, yang paling berkontribusi terhadap besaran indeks WWL bidan di Puskesmas Jetis Yogyakarta adalah dimensi 
tuntutan waktu. Tuntutan waktu merupakan besarnya tekanan waktu yang dirasakan selama melakukan pekerjaan.

Tuntutan waktu yang dirasakan bidan Poli KIA adalah terkait ketepatan dan kesigapan dalam memberikan pelayanan kebidanan dalam waktu yang terbatas. Waktu pelayanan yang terbatas dengan jumlah pasien yang banyak menuntut bidan untuk bekerja secara cepat. Hal ini sejalan dengan hasil penelitian Widayati dkk (2014) menyatakan bahwa pelaksanaan petugas dalam memberikan pelayanan dipengaruhi oleh banyaknya pasien yang dilayani. Bidan harus dapat membagi waktu untuk semua pasien sehingga hanya ada waktu sedikit untuk setiap klien.

Tuntutan waktu pada bidan di unit rawat inap bersalin adalah berupa kesigapan dalam menolong persalinan karena berkaitan dengan nyawa pasien baik ibu dan bayinya. Pekerjaan yang menuntut waktu yang menambah beban adalah adanya tugas administrasi. Tugas administrasi berupa pencatatan dan pelaporan yang harus diselesaikan tiap harinya agar setiap bulannya dapat dikumpulkan ke instansi terkait tepat waktu sesuai dengan ketentuan. Hal ini didukung dengan hasil penelitian Widayati dkk (2014), bahwa masih banyak bidan yang mengatakan tidak ada waktu yang cukup untuk istirahat dan melakukan pendokumentasian.

Pada hasil penelitian ini yang menunjukkan skor ke dua tertinggi adalah tingkat usaha. Tingkat usaha dalam pekerjaan sebagai bidan adalah besarnya usaha yang harus dikeluarkan baik secara fisik dan mental untuk menyelesaikan pekerjaanya. Salah satu tingkat usaha yang ditunjukkan dalam pelayanan di Poli KIA adalah tetap memberikan pelayanan kebidanan sampai selesainya pasien meskipun harus mengorbankan waktu istirahatnya. Tingkat usaha bidan di unit rawat bersalin adalah tetap siap memberikan pelayanan kebidanan terutama persalinan kapan saja selama 24 jam disesuaikan dengan shift kerja. Tidak jarang bidan di unit rawat berjaga semalaman untuk mengobservasi pasien bersalin dan stand by setiap saat karena kondisi pasien yang dapat berubah sewaktu-waktu.

Dimensi terakhir dengan skor tertinggi adalah tuntutan mental. Dalam pekerjaannya, tuntutan mental profesi sebagai bidan adalah besarnya aktivitas mental dan perseptual yang dibutuhkan dalam pekerjaan pelayanan kebidanan. Seorang bidan dituntut selalu siap secara fisik dan psikis serta memiliki ketelitian, kesabaran, dan ketanggapan yang cukup tinggi dalam menangani pasien karena pekerjaannya yang menyangkut nyawa seseorang (Yolanda, 2014).

Tuntutan mental berdasarkan Tabel 5, hasil identifikasi pada bidan adalah pada saat anamnesa pasien. Bidan berusaha menggali informasi untuk mengkaji dan menentukan diagnosa dengan dibuktikan melalui hasil pemeriksaan fisik. Oleh sebab itu bidan harus menciptakan suatu rasa percaya diri sehingga pasien akan lebih mudah terbuka mengungkapkan keluhannya. Jika bidan dapat memahami kebutuhan pasien maka akan memudahkan bidan untuk merencanakan tindakan selanjutnya. Pada saat melakukan konseling maupun menjelaskan hasil pemeriksaan, bidan harus dapat memberikan pemahaman kepada pasien maupun keluarga terkait kondisi kesehatan.

Menurut Tabel 5, beban mental terberat bidan di Poli KIA menurut hasil identifikasi adalah pada saat anamnesa pasien. Dengan jumlah pasien yang banyak dan waktu yang terbatas bidan harus berusaha menggali informasi dengan cara memahami dan memperhatikan kebutuhan pasien. Beban mental tambahan bidan di Poli KIA adalah mengevaluasi program kesehatan ibu dan anak yang hampir semuanya dijalankan oleh bidan Poli KIA. Untuk dapat mengevaluasi program KIA, bidan terlebih dahulu melengkapi pencatatan pelaporan seperti Kohort, laporan dari fasilitas kesehatan lainnya di wilayah kerja Puskesmas Jetis.

Tuntutan mental pada bidan di unit rawat inap bersalin berdasarkan Tabel 5 adalah ketepatan dalam mengkaji kondisi pasien untuk menentukan diagnosa sehingga dapat merencanakan tindakan yang tepat. Bidan rawat inap menghadapi pasien bersalin yang kondisinya lebih berisiko. Bidan juga harus terlebih dahulu memperkirakan risiko dari setiap tindakan yang dilakukan dengan mengutamakan keselamatan pasien. Persiapan mental yang baik akan memberikan ketenangan dalam melakukan tindakan dan pengambilan keputusan. Bidan tidak hanya menghadapi pasien saja namun juga harus berurusan dengan keluarga pasien. Bidan harus pandai memberikan pemahaman kepada keluarga terkait kondisi kesehatan pasien dan pengambilan keputusan.

Berdasarkan hasil pengukuran dengan NASATLX dimensi yang memperoleh skor terendah adalah tingkat frustasi, tuntutan fisik, dan performansi. Tingkat frustasi dalam pekerjaan sebagai bidan adalah besarnya perasaan tidak aman, putus asa, tersinggung dibandingkan dengan perasaan aman, nyaman, dan kepuasaan yang dirasakan oleh bidan. 
Rasa frustasi merupakan perasaan adanya halangan untuk memenuhi keinginan (Istirohah, 2015). Seorang bidan dalam menjalankan pekerjaan terlebih dahulu memastikan setiap tindakan yang dilakukan sudah sesuai dengan prosedur agar tidak terjadi hal yang tidak diinginkan seperti terjadinya perdarahan post partum, kecacatan akibat salah prosedur, asfiksia, bahkan hingga terjadinya kematian pada ibu maupun bayi. Jika hal yang tidak diinginkan sampai terjadi dapat memberikan efek psikis seperti kecemasan, stress, rasa bersalah, dan efek psikologi lainnya.

Pada penelitian ini, tingkat frustasi bidan memperoleh skor yang rendah dapat dikarenakan faktor masa kerja bidan rata-rata selama 17 tahun. Masa kerja tersebut membuktikan bahwa sebagian responden telah memiliki banyak pengalaman di bidang asuhan kebidanan, sehingga mampu dan memiliki mekanisme coping tersendiri dalam mengatasi masalah yang muncul dalam pekerjaannya (Maharja, 2015). Masa kerja secara signifikan dapat meningkatkan kinerja pegawai (Hardikriyawan \& Margono, 2014). Masa kerja yang semakin lama akan memengaruhi kualitas kerja yang berujung pada perbaikan kinerja seorang pegawai. Kinerja berkaitan erat dengan beban kerja mental, beban kerja mental yang sesuai akan menghasilkan kinerja yang optimal (Wulanyani, 2013).

Dimensi terendah kedua yaitu tuntutan fisik. Tuntutan fisik seorang bidan adalah banyaknya aktivitas fisik yang dibutuhkan dalam melaksanakan pelayanan kebidanan. Berdasarkan Tabel 4, penilaian subyektif beban kerja fisik yang mendominasi di Poli KIA pada pelayanan kehamilan. Berdasarkan Badan PPSD Kesehatan (2015), norma waktu pelayanan kehamilan pada bidan di Puskesmas rawat inap adalah 30 menit. Pada pelayanan kehamilan di Puskesmas Jetis membutuhkan waktu yang lebih lama dan beberapa tahapan pemeriksaan terlebih dahulu seperti pemeriksaan laboratorium, pemeriksaan gigi, pemeriksaan USG oleh dokter, konseling gizi. Tahapan pemeriksaan tersebut terkadang membuat pelayanan kehamilan membutuhkan waktu yang lebih lama karena proses mengantre di poli lain yang tak tentu. Bidan di Poli KIA mempunyai tuntutan waktu dalam melayani tiap pasien karena jumlah pasien yang banyak sedangkan waktu pelayanan yang terbatas sampai semua pasien selesai dilayani. Oleh sebab itu bidan bekerja secara cepat namun dituntut memiliki ketepatan dalam mendiagnosa dan kesigapan dalam memberikan pelayanan kebidanan.
Hasil identifikasi penilaian subyektif beban kerja fisik yang mendominasi di unit rawat inap bersalin pada pelayanan persalinan. Hal ini disebabkan karena prosedural pelayanan persalinan membutuhkan waktu yang tak menentu disesuaikan dengan kondisi pasien. Pada pelayanan persalinan mempunyai risiko yang lebih besar dibandingkan dengan pelayanan kebidanan lainnya di unit rawat inap bersalin. Bidan mempunyai beban ganda untuk menyelamatkan nyawa ibu dan bayinya. Oleh sebab itu dalam proses menolong persalinan membutuhkan keadaan fisik yang baik.

Tugas seorang bidan selain melaksanakan pelayanan kebidanan (tugas pokok dan tugas integrasi), terdapat tugas tambahan yaitu tugas administrasi. Hal ini sejalan dengan hasil penelitian Suparti (2010), bahwa 100\% bidan menyatakan harus menyelesaikan tugas-tugas yang bersifat administratif. Hasil dalam penelitian ini menunjukkan sebagian besar responden yaitu 9 responden (60\%) menyatakan tugas administrasi dirasa lebih berat dibandingkan tugas pelayanan kebidanan.

Dimensi terakhir yang memperoleh skor terendah adalah performansi. Performansi merupakan kepuasaan yang dirasakan oleh bidan terhadap pelayanan kebidanan yang telah diberikan. Kepuasaan akan diperoleh apabila aspek pekerjaan dan aspek dirinya mendukung. Jika sebaliknya, aspek tersebut tidak mendukung maka pegawai akan merasa tidak puas. Kondisi kepuasan atau ketidakpuasan kerja tersebut, akan menjadi umpan balik yang akan memengaruhi kinerja karyawan pada suatu perusahaan (Vidianingtyas, 2014). Menurut hasil penelitian Artadi (2014), kinerja dipengaruhi oleh beban kerja. Jadi jika dimensi performansi memperoleh nilai terendah maka pembebanan kerja pada bidan dikatakan rendah dapat dikarenakan bidan di Puskesmas Jetis bekerja secara tim.

\section{Kelelahan Kerja Bidan di Puskesmas Jetis Yogyakarta}

Menurut Sedarmayanti (2011), kelelahan kerja merupakan suatu pola yang timbul pada keadaan tertentu yang secara umum terjadi pada setiap orang yang tidak sanggup lagi untuk melakukan kegiatan. Kriteria kelelahan kerja tidak hanya berupa kelelahan fisik dan psikis, namun berkaitan dengan adanya penurunan kinerja fisik, adanya perasaan lelah, penurunan motivasi, dan penurunan produktivitas kerja (Maurits, 2010). Hasil pada penelitian ini menunjukkan bahwa $60,0 \%$ responden memiliki 
kelelahan kerja yang dikategorikan sedang, dan 40,0\% dikategorikan tingkat kelelahan rendah.

Hasil penelitian menunjukkan sebagian besar responden berada di tingkat kelelahan sedang. Berdasarkan penelitian Nisa' (2013), masa kerja memengaruhi keluhan kelelahan kerja. Ratarata masa kerja sebagai bidan di Puskesmas Jetis Yogyakarta adalah 17 tahun, sehingga kemungkinan besar timbul rasa kebosanan dengan rutinitas yang sama selama bertahun-tahun. Suasana yang monoton akan berakumulasi menjadi rasa bosan dan memengaruhi tingkat kelelahan. Kelelahan semakin meningkat dengan adanya masalah di luar pekerjaan seperti masalah keluarga. Sebanyak 13 responden $(86,7 \%)$ berstatus menikah. Jika sudah berkeluarga maka akan menambah beban tersendiri baik secara mental dan fisik karena masalah yang dihadapi bukan hanya tentang pekerjaan namun segala urusan rumah tangga. Hal ini sejalan dengan hasil penelitian Nisa (2013), yang menyatakan bahwa status perkawinan berpengaruh pada keluhan kelelahan kerja.

Pada penelitian ini diperoleh hasil sebesar $46,7 \%$ responden berusia $\geq 40$ tahun dengan responden tertua berusia 55 tahun. Faktor usia memengaruhi tingkat kelelahan kerja (Oesman \& Simanjuntak, 2011). Semakin tua usia seseorang akan terjadi penurunan faktor fisik, dan semakin kompleksnya permasalahan yang dihadapi sehingga memengaruhi tingkat adaptasi seseorang di lingkungan kerjanya dan meningkatkan keluhan mental. Usia seseorang akan memengaruhi kondisi, kemampuan, dan kapasitas tubuh dalam melakukan aktivitasnya. Proses penuaan menyebabkan adanya perubahan pada organ tubuh manusia, sistem kardiovaskuler, hormon, dan lainnya (Suma'mur, 2010). Usia yang bertambah tua juga memengaruhi kondisi kesehatan seseorang. Sebanyak 6 responden $(40,0 \%)$ yang mempunyai riwayat penyakit yaitu diabetes mellitus, hipertensi, dan asma. Kelelahan pada seseorang juga dapat terjadi dari riwayat penyakit yang berkontribusi menimbulkan kelelahan seperti diabetes mellitus (Andiningsari, 2009). Hal tersebut semakin menambah keluhan kelelahan.

Seorang Bidan mempunyai tugas utama memberikan pelayanan kebidanan dan tugas tambahan berupa tugas administrasi. Untuk memberikan pelayanan kebidanan, sebanyak 12 responden $(80,0 \%)$ membutuhkan waktu $>4$ jam, sedangkan waktu yang dibutuhkan menyelesaikan tugas administrasi $<2$ jam. Hasil wawancara dengan bidan di Poli KIA mengatakan bahwa tidak ada jam istirahat yang pasti sampai selesainya pasien. Sedangkan, di unit rawat inap bersalin waktu istirahat lebih fleksibel dan cenderung lebih santai dibandingkan dengan poli KIA karena pasien yang ditangani lebih sedikit. Meskipun pasien yang ditangani lebih sedikit namun membutuhkan kesiapan, kesigapan, dan kewaspadaan tinggi dalam penanganan pasien karena yang dihadapi adalah pasien bersalin yang kondisinya tidak dapat diprediksi.

Pada penelitian ini juga diperoleh data bahwa 6 responden $(40,0 \%)$ termasuk dalam kelelahan tingkat rendah. Hal ini dapat disebabkan sebagian besar responden berusia $<40$ tahun sebesar $(53,2 \%)$. Usia yang masih tergolong produktif ditunjang dengan kondisi fisik yang masih baik maka keluhan kelelahan kerja tidak sebesar dengan responden lain yang usianya $\geq 40$ tahun. Status gizi yang menunjukkan hasil $73,3 \%$ responden memiliki indeks massa tubuh normal. Status gizi yang baik dengan jumlah asupan kalori dalam jumlah dan waktu yang tepat berpengaruh positif terhadap daya kerja. Apabila asupan kalori seseorang tidak sesuai dengan kebutuhannya maka lebih cepat merasakan lelah dibandingkan dengan seseorang dengan asupan kalori yang mamadai (Atiqoh dkk, 2014). Status gizi yang baik juga turut andil memengaruhi kondisi kesehatan. Sebagian besar responden tidak memiliki riwayat penyakit yang dapat memengaruhi tingkat kelelahan. Sebesar 93,3\% responden tidak memilki klinik pribadi atau bekerja di tempat lain sehingga mengurangi keluhan kelelahan kerja. Kemampuan fisik yang masih baik, sistem kerja di Puskesmas Jetis dalam bentuk tim. Di Poli KIA terdapat 4 bidan, dan di unit rawat inap bersalin terdapat 11 bidan dengan tiap shift kerja terdapat 2-3 orang bidan. Bekerja secara tim terdapat pembagian tugas sehingga mengurangi beban kerja.

\section{SIMPULAN}

Sebagian besar yaitu $53,3 \%$ bidan berumur $<40$ tahun, $80,0 \%$ bidan berpendidikan terakhir D3, $60,0 \%$ bidan memiliki masa kerja di Puskesmas Jetis selama $<5$ tahun, dan 53,3\% bidan memiliki masa kerja sebagai bidan $<17$ tahun. Sebagian besar yaitu $73,3 \%$ bidan memiliki indeks massa tubuh normal $(73,3 \%)$, dan $60,0 \%$ bidan tidak memiliki riwayat penyakit, serta $73,3 \%$ bidan tidak rutin berolahraga. Hasil penelitian ini menunjukkan bahwa beban kerja mental pada pekerjaan bidan lebih besar 
dibandingkan dengan beban kerja fisik, dan ratarata bidan mengalami kelelahan kerja tingkat sedang $(60,0 \%)$.

Kelelahan kerja dapat dihindari dengan melakukan pengaturan ulang shift kerja sesuai dengan aturan dan syarat-syarat ketentuan shift kerja pada unit rawat inap bersalin, penentuan jam istirahat yang jelas, saat jam pelayanan dapat diiringi dengan musik kerja, dan rutin melaksanakan refreshing untuk mengurangi kejenuhan.

\section{DAFTAR PUSTAKA}

Andiningsari, P. 2009. Hubungan Faktor Internal dan Eksternal Pengemudi terhadap Kelelahan pada Pengemudi Travel X-Trans Jakarta Trayek Jakarta-Bandung Tahun 2009. Skripsi. Universitas Indonesia. Tersedia di : lib.ui.ac.id/ file?file=digital/125826-S-5848...Literatur.pdf. [ diakses pada tanggal 11 April 2016].

Artadi, F.F. 2014. Pengaruh Kepuasan Kerja dan Beban Kerja terhadap Kinerja Karyawan pada PT Merapi Agung Lestari. Skripsi. Universitas Negeri Yogyakarta. Tersedia di : http://eprints.uny. ac.id/16338/1/FebriFurqonArtadi_10408141043. pdf [diakses pada tanggal 29 Januari 2017].

Atiqoh, J., Wahyuni, I., Lestantyo, D. 2014. FaktorFaktor yang Berhubungan dengan Kelelahan Kerja pada Pekerja Konveksi Bagian Penjahitan di CV. Aneka Garment Gunungpati Semarang. Jurnal Kesehatan Masyarakat (e-Journal), Volume 2, Nomor 2, Pebruari 2014. Tersedia di: http://download.portalgaruda.org/ [diakses tanggal 30 April 2016].

Handayani, L, Ma'ruf N.A., Sopacua E. 2010. Peran Tenaga Kesehatan Sebagai Pelaksana Pelayanan Kesehatan Puskesmas. Buletin Penelitian Sistem Kesehatan-Vol.13 No. 1 Januari 2010: 12-20. Tersedia di : http://ejournal.litbang.depkes.go.id/ index.php/hsr/article/view/2752 [diakses pada tanggal 05 April 2016].

Hardikriyawan, A., Margono. 2014. Pengaruh Pelatihan dan Masa Kerja terhadap Kinerja Pegawai (Studi pada Kantor Badan Pusat Statistik Kota Probolinggo). Jurnal Ilmiah Mahasiswa FEB Vol 3, No 1: Semester Ganjil 2014/2015 Tersedia di: http://id.portalgaruda.org/?ref=bro wse $\& \bmod =$ viewarticle $\&$ article $=285414$ [diakses pada tanggal 07 November 2016].

Hidayat, A., Mufdlilah. 2008. Catatan Kuliah Konsep Kebidanan Plus Materi Bidan Delima. Yogyakarta: Mitra Cendekia.
Humas Pemkot Yogyakarta. 2014. Info Kota : 6 Puskesmas Kota Yogya Terima ISO. Tersedia di: http://www.jogjakota.go.id/news/6-PuskesmasKota-Yogya-Terima-Iso [diakses pada tanggal 14 April 2016].

Istirohah, N. 2015. Frustasi sebagai Dampak Psikologis Kegagalan Keberangkatan Para Calon Jamaah Haji Tahun 2013 di Kota Semarang dan Solusinya dalam Perspektif Bimbingan dan Konseling Islam. Skripsi. Universitas Islam Negeri Walisongo. Tersedia di: http://eprints. walisongo.ac.id/4789/1/101111030.pdf [diakses pada tanggal 29 Januari 2017].

Keputusan Menteri Kesehatan Republik Indonesia Nomor 836/Menkes/SK/VI/2005 Tentang Pedoman Pengembangan Manajemen Kinerja Perawat dan Bidan. Tersedia di : http://dinkes. surabaya.go.id/portal/ [diakses pada tanggal 8 April 2016].

Keputusan Menteri Kesehatan Republik Indonesia Nomor: 369/MENKES/SKIII/2007 Tentang Standar Profesi Bidan. Tersedia di: perpustakaan. depkes.go.id:8180/bitstream/.../4/BK2008-G118. pdf [diakses pada tangggal 04 April 2016].

Keputusan Walikota Yogyakarta Nomor: 123/ KEP/2013 Tentang Rumah Sakit Pelayanan Obstetri Neonatal Emergensi Komprehensif (PONEK) dan Puskesmas Pelayanan Obstetri Neonatal Emergensi Dasar (PONED) Di Kota Yogyakarta. Tersedia di : http://hukum.jogjakota. go.id/data/Binder16.pdf.

Maharja, R. 2015. Analisis Tingkat Kelelahan Kerja Berdasarkan Beban Kerja Fisik Perawat di Instansi Rawat Inap RSU Haji Surabaya. Indonesian Journal of Occupational Safety and Health, Vol. 4, No.11 Jan-Jun 2015: 93-102. Tersedia di : e-journal.unair.ac.id/index.php/ IJOSH/article/download/1651/1272 [diakses pada tanggal 6 April 2016].

Mauludi, M.N. 2010. Faktor-Faktor yang Berhubungan dengan Kelelahan pada Pekerja di Proses Produksi Kantong Semen Pbd (Paper Bag Division) Pt. Indocement Tunggal Prakarsa Tbk Citeureup-Bogor Tahun 2010. Skripsi. Universitas Islam Negeri Syarif Hidayatullah Jakarta. Tersedia di: http://repository.uinjkt.ac.id/ [diakses pada tanggal 29 April 2016].

Maurits, L.S. 2010. Selintas Tentang Kelelahan Kerja. Yogyakarta: Amara Books.

Nisa', AZ. 2013. Faktor yang Memengaruhi Keluhan Kelelahan pada Teknisi Gigi di Laboratorium Gigi Surabaya. Indonesian Journal of Occupational 
Safety and Health, Vol. 2, No. 1 Jan-Jun 2013: 61-66. Tersedia di: journal.unair.ac.id/downloadfullpapers-k372e5127c68full.pdf [diakses pada tanggal 30 April 2016].

Oesman, T.I., Simanjuntak, R.A. 2011. Hubungan Faktor Internal dan Eksternal terhadap Kelelahan Kerja Melalui Subjective Self Rating Test. Proceeding $11^{\text {th }}$ National Conference of Indonesian Ergonomics Society ISSN 4: 20889488 Workplace Safety and Health I-268 - I-276. Tersedia di: http://repository.akprind.ac.id/ [diakses pada tanggal 30 April 2016].

Pusat Perencanaan dan Pendayagunaan SDM Kesehatan. 2015. Buku Manual 1 Perencanaan Kebutuhan SDM Kesehatan Berdasarkan Metode Analisis Beban Kerja Kesehatan (ABK Kes). Tersedia di: http://skpd.pacitankab.go.id/ [diakses pada tanggal 05 Februari 2017].

Peraturan Menteri Kesehatan Republik Indonesia Nomor: 551/MENKES/Per/VII/2009 Tentang Petunjuk Teknis Jabatan Fungsional Bidan dan Angkat Kreditnya. Tersedia di: http:// simpadubuk.net/file/ [diakses pada tanggal 07 Februari 2017].

Sedarmayanti. 2011. Tata Kerja dan Produktivitas Kerja. Bandung: CV Mandar Maju.

Suma'mur, PK. 2010. Higiene Perusahaan dan Keselamatan Kerja. Jakarta: CV Sagung Seto.

Suparti, P. 2010. Analisis Kinerja Bidan di Desa dalam Penjaringan Balita Gizi Buruk di Kabupaten Kendal. Tesis. Universitas Diponegoro. Tersedia di: http://eprints.undip. ac.id/23744/1/Padmi_Suparti.pdf [diakses pada tanggal 20 November 2016].

Vidianingtyas, R.N. 2014. Pengaruh Kompensasi, Kepuasan Kerja, Motivasi Kerja dan Gaya Kepemimpinan terhadap Kinerja Karyawan Pada Perusahaan Jasa Catering di Daerah Istimewa Yogyakarta. Efektif. Jurnal Bisnis dan Ekonomi Vol. 5, No. 1, Juni 2014, 99-110. Tersedia di http://jurnalefektif.janabadra.ac.id/wp-content/ uploads/2015/11/Efektif-Juni-2014_7.pdf [diakses pada tanggal 29 Januari 2017].

Wahyuni, E. 2015. Analisis Beban Kerja Bidan Desa dalam Melaksanakan Kewenangannya di Wilayah Kerja Puskesmas Gladak Pakem Kabupaten Jember. Skripsi. Universitas Jember. Tersedia di: http://repository.unej.ac.id/ handle/123456789/66188 [diakses pada tanggal 24 Januari 2017].

Widayati, R.S, Widagdo L, Purnami C.T. 2014. Analisis Pelaksanaan Konseling Kontrasepsi oleh Bidan di Wilayah Dinas Kesehatan Kota Surakarta. Gaster Jurnal Ilmu Kesehatan Vol.11 No. 2 Februari 2014. Tersedia di : http:// www.jurnal.stikes-aisyiyah.ac.id/index.php/ gaster/article/view/72 [diakses pada tanggal 26 Januari 2017].

Wicaksono, A. 2014. Pengaruh Beban Kerja Fisik terhadap Kelelahan Kerja di Bagian Produksi Tulangan Beton PT Wijaya Karya Tbk. Beton Boyolali. Skripsi. Universitas Muhammadiyah Surakarta. Tersedia di: eprints. ums.ac.id/31191/13/Naskah_Publikasi.pdf [ diakses pada tanggal 11April 2016].

Wulanyani, N.M.S. 2013. Tantangan dalam Mengungkap Beban Kerja Mental. Buletin Psikologi Volume 21, No 2, Desember 2013: 80 -89 Fakultas Psikologi Universitas Gadjah Mada ISSN: 0854-7108. Tersedia di: http://download. portalgaruda.org/ [diakses pada tanggal 08 November 2016].

Yolanda, N. 2014. Analisis Hubungan Faktor Pekerjaaan dengan Stress Kerja Bidan di Rumah Sakit Syamrabu Bangkalan. Indonesian Journal of Occupational Safety and Health, Vol. 3, No. 2 Jul-Des 2014: 138-147. Tersedia di: http:// journal.unair.ac.id/ [diakses pada tanggal 19 Maret 2016]. 